\title{
Itouse of Cummons Befates
}

\section{FIFTH SESSION-SEVENTH PARLIAMENT}

\section{SPEECHES}

OF

\section{H. W. ALLAN, M.P. and W. McGREGOR, M.P.}

\section{FISHERIES OF THE GREAT LAKES}

OTTAWA, FRIDAY, 5TT JULY, 1895.

Mr. ALLAN. Mr. Speaker, I desire to refer to the fishery interests of the Great Lakes, and to say a few words respecting the fishery policy of the Government. You will recollect, Mr. Speaker, that I brought this question before the House at the last session of Parliament. On that occasion my time before six o'clock was very limited, and, being unable to be present after recess, I was prevented from entering into the discussion of the subject as fully as I intended. The then Minister ef Marine and Fisheries followed in a very lengthy speech, giving an elaborate review and defence of his so-called fishery policy. The hon. gentleman wals evidently very proud of that great effort, for his speech was put in pamphlet form and widely distributed throughout the fishery districts. I am very glad that he did so, because his defence was simply no defence at all, and the people were enabled to see that there is practically no justificatlon whatever for the extraordinary and ruinous fishery policy of this Government.

'The lon. gentleman's speech was a very characteristic one-slightly tinged with extrivarance in tone and a tritle reckless in statement. In fact, all the important statements made by the hon. gentleman were utterly without foundation. The most important statement he made was that our fisheries had been depleted, which he ascribed to overfishing in Canadian waters. If that statement were true, It would remove, to a very great extent, the ground of complaint against this fishery policy, made not only to-day, but for years past. The charge has been that Canadians were not permitted to fish-that they were not permitted to enjoy the profits of the vast trade that has been carried on for many years. in the Lake Erie fisheries. Overfishing! Why, Sir, the statement is absurd. An examination of the statistics bearing on this subject will conclusively prore that. When we look at the comparative catch on both sides of the lake, what do we find ? That in twenty years the American fishermen have caught, on the American side of Lake Erie, not less than $800,000,000$ pounds of fish more than have been caught on the Canadian side. Hon. gentlemen from Nova Scotia can comprehend the magnitude of these figures. Why, Sir, it would take the entire catch of the 24,000 fishermen of Nova Scotia for elght years to make up this excess. The annual catch in Lake Erie on the American side has been double the entire Canadian eatch of fish in the whole chain of lakes-Lake Superior, Lake St. Clair, Isake Huron, Lake Erie and Lake Ontario. The American fishel'men haye caught eight tish to our one, and this has been going on continuously ever since 1870. and in fact in all the past yeal's of which we have any record. The yeople have protested against this policy for years. Year by year they have been pointing to the fact that, owing to the polley of the Department of Fisheries, a vast and 
profitable trade has been thrown almost entire:y into the liands of the American people. And yet the Minister of Justice could have the assurance to get up in this House and state that our fisheries in Iake Erie have been depleted from overfishing. Fe declared that no member from ine Lake Erie district would rise in his place in this House and state that the Lake Frie fisheries on both sides have withstood successfully the onslaught made year by year upon them. There have been no onslaught.s, there has been no overfishing, on the Canadian sirle of Ialie Erie. The rery fact that the Anericans have cauglit this great quantity in excess of the Canadian catch, and are continuing to the present day to catch Fearly from $40,000,000$ to $50,000,000$ pounds in excess of the Canadian catch, amply proves the statement I have made. Now, Sir, if the Americans did not take a single fis! out of Iake Erie, they are ahead of us one hundred years in the catch of the last twenty years; that is, it would take the Canadian fishermen 100 years to make good the excess of the fish caught on the American side in the last 20 years. And yet the Minister of Justice tells the House and the country that there has been overtishing on our side. Our fisheries are as good as theirs; they are said to be better. In the great waters that divide the two countries we have an equal interest; but if we examine the statistics bearing on the subject-and it is necessary to do so in order to obtain an intelligent view of the whole matter-the figures will sliow that in the production of the fishe:ies, Canada. has had a very unequal share.

This is very apparent from an examination of the figures in relation to the different lakes. Take Lake Erie. The catch on both sides of Lake Erie in the years 1880, 1885, and 1889, which are years for. which we can compare our figures with those furnished by the United States census, are as follows :-

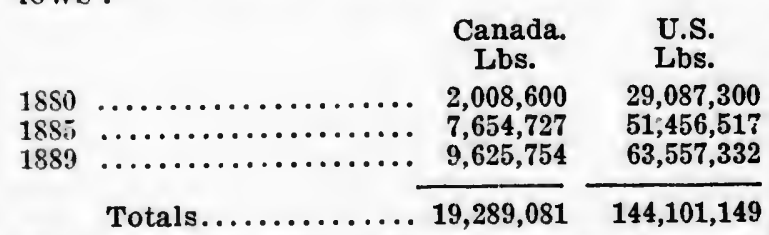

The average catch in these three years was In Canada, 6,429,694 pounds; and in the Lnited States, $48,033,716$ pounds ; or nearly elght times greater than the average catch in Canada. Taking the average catch for these three years as a basis, the total catch fol the ten years from 1880 to 1889 , inclusive, was as follows :-

Lbs.

Canada ...................... 64,296,940 United States ................480,033,716

Excess in favour of the United States

for the ten years...............415,736,776

The excess in value, according to the values used by the Department of Marine and Fisheries, would be about $\$ 20,000,000$. The Americans caught more fish in Lake Erie in ten years than Canada will catch in seventy years under this one-sided policy of the Government. And, Sir, in the presence of such figures as these, which are taken from the blue-books, we have the hon. Minister of Justice making this statement in the House last year :

All twis talk about the fishery sta.: tics of United $S$ tates ports on Lake Erie is noti.ing but talk, becailse 1 have given evidence to show that fisheries in Lake Erie, where people have been allowed to fish ab libitum, unrestricted by Government interference, are already a thing of the past; and when the hon. gentleman reads these statistics, I will tell him how they are made, and I will give him good authority. These statistics are made up of Canadian fish. These fisheries have assumed enormous importance since the passage of the McKinley Bill, and with what result ? The hon. gentleman has told us in part. He has told us that our fisheries are largely in the hands of the United States fish-dealers in Buffalo and elsewhere, owing largely to circumstances over which we have had practically no control.

Now, this is a remarkable statement. The actual figures show that the excess in ten years is over $400,000,000$ pounds, and the figures I gave the House on that occasion were figures existing before the passage and operation of the McISinley Bill; and if we allowed every pound of fish to be entered, as the hon. gentleman said some tons of fish were shipped to the United States and entered, it would have yery slight effect upon the figures l ii:lvc given. Our catch is only 7,000,000 $\mathrm{cr}$ $\mathbf{8 , 0 0 0 , 0 0 0}$ pounds; their catch is $3,0 .-$ 000,000 pounds, and the hon. gentleman gets up in this House and coolly tells the Parliament anc people of Canada that the statistics relating to the exports of fish are made up now by our fish entered under the McKinley Bill. Why, the extravagance of the statement of the hon. gentleman is really surprising. It is difficult to understand how a Minister of the Crown can get up and makje such statements.

But there is a more serious aspert still in the statements of the blue-books of the country. Year after year we have founü similar statements made with leference to our fisheries, and made, no doubt, under the authority of the Minister of Mariue and Fisheries. In the blue-books of this country, in the face of these figures which are actual figures, an attempt is made to show that the contention that the Arrericans are getting an advantage in respect of the lake fisheries is simply a contention without basis. I notice in the bluebooks of 1890,1891 and 1893 these false comparisons are made. I would like to ask the hon. Minister how he can justify statements made up by comparisons such as the following. He will put down American herriugs at about 1 cent a pound and herrings 
caught upon the Canadian side at 3 cents a pound. Canadian whitefish he enters at 8 cents a pound. and American whitefish, which is caught in the same waters and is really worth more, because it is right in the inarket where the fish are sold, he deliberately puts down at one-third of the value, and in this way statistics relative to our fisheries have been made up from year to year. That there may be no misrepresentation in reference to this matter, I will just read what appears in the bluebooks, and I find that similar statements have appeared in the different blue-books for three or four successive years.

Catch of fish on loth sides of the Great Lakes in the years $1880,185.5$ and 1859.

\begin{tabular}{|c|c|c|}
\hline Year. & Quantity. & Value.* \\
\hline 1880. & Lbs. & \\
\hline 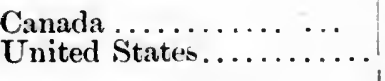 & $\begin{array}{l}11,473,000 \\
45,600,000\end{array}$ & $\begin{array}{l}416,791 \\
984,500\end{array}$ \\
\hline 1885. & & \\
\hline $\begin{array}{c}\text { Canada } \ldots \ldots \ldots \ldots \ldots \ldots \\
\text { United States.......... } \\
1889 .\end{array}$ & $\begin{array}{l}2 \pi, 378,180 \\
76,423,728\end{array}$ & $\begin{array}{l}1,268,551 \\
1,813,078\end{array}$ \\
\hline 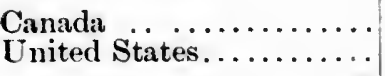 & $\begin{array}{l}29,198,359 \\
91,076,624\end{array}$ & $\begin{array}{l}1,816,462 \\
1,827,248\end{array}$ \\
\hline
\end{tabular}

* According to report of Department of Marine and Fisheries for 1891 .

I wish to direct the attention of the House to the manner in which these statistics are made up. In 1880 the entire catch on the Canadian side of the lakes was $11,473,000$ pounds of tish, the value of which, according to the Department of Marine and Fisheries, was $\$ 416,791$. The entire catch on the American side of the lake was $45,600,000$ pounds, and the value, according to the Department of Marine and Fisheries, was $\$ 984,500$. In 1855, the Canadian catch was $27,378,150$ pounds, valued at $\$ 1,268,551$, and the United

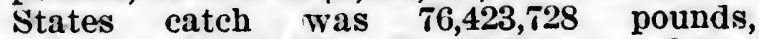
valued at $\$ 1,813,078$. In 1889 , the Canadian catch was $29,198,359$ pounds, valued at $\$ 1,816,462$, and the United States catch was $91,076,624$ pounds, ralued at $\$ 1,827,214$. Now, Sir, in 1880, 11,000,000 pounds of Canadian fish was valued it about half as much as $45,000,000$ pounds of the same kind of fish caught on the other side of the lake. In $1885,27,000,000$ pounds of Canadian fish was valued at two-thirds as much as $76,000,000$ pounds of American fisl ; and in 1889, 29,000,000 pounds of Canadian fish were- valued at nearly the same figures as $91,000,000$ pounds of Amerlcan fish, or within $\$ 10,000$ of the amount.

These are extraordinary figures. I called the attention of hon. gentlemen to them at the last session of Parliament. The hon. gentleman may make any sort of statement to the House, I suppose, but there is no way of preventing him doing that sort of thing, but here are the blue-books of Canada cooked for a special purpose, and designedly cooker, because these misrepresentations appear in one bluebook after another. I would like to know how the hon. gentleman will explain putting down herrings at 3 cents a pound, when they are ralued in the United States at 1 cent a pound, and whitefish at 8 cents, when the wholesale price in the market is $\$ 4$, or not more than $4 \frac{1}{2}$ cents ; trout at 10 cents, when the wholesale price is $\$ 4$. Evidently the statistics bearing upon the fisheries question are made up in this way in order to make a favourable slowing, and American fish are ralued at one-third less than Canadian fish.

Now, I have alluded to the Lake Erie fisheries. Fully one-half of this enormous business in the fisheries is carried on almost opposite the county of Essex. But the bon. gentleman alluded to that as a trifling matter and a mere bagatelle. He said :

In order to put the matter in its strongest light, as I have said, the hon. gentleman dwelt upon a comparatively small strip of water, where a very few men have been engaged in the fishing business. The amount is a mere bagatelle. That is their strong point, and they bring that up as an evidence of the hardship of the case. I meet them by saying, that although the subject came up earlier in the session and we are now in June, yet I have to learn the name of one solitary individual who has been ruined or injured by the enforcement of a necessary and wholesome regulation.

This is another of the hon. gentleman's very extravagant statements. He has yet to learn that one solitary person has been injured by the wholesome and necessary regulations. Well, the statement is somewhat involved. If the regulations were wholesome and necessary, perhaps no fishermen would be injured, but as a matter of fact every single regulation in connection with our fisheries has hampered and injured our fishermen. The hon. gentleman has reduced the gill-net. It will take about as many men to fish with the one pound-net as with ten pound-nets, yet his policy is only to allow one pound-net to our fishermen. The result is that they are handicapped and cannot fish to advantage. Four men cr.n fish ten pound-nets. Here is one of the regulations by which the fishermen are injured. Then again in reference to gill-nets. The department has reduced the allowance of gill-net to one boat to 6,000 yards. The hon. Minister must know that this regulation is violated. It is violated, I suppose, in 75 per cent of cases. The fishermen do not pretend to live up to it. The allowance of gill-netting for tugs was cut domn to 12,000 yards ; and, Sir, it is well known that the tugs are using two or three times that 
quantity. I suppose the hon. Minister knows that. Here, then, is a regulation that is being vlolated all over the lakes. Recently a challenge was issued to the department to deny this. I refer to an article published in the Toronto "News" on the subject of "Fishery Frauds," which I will read :

Editor "News."-Having long been a supporter of the Conservative party, and occupying a somewhat prominent position in the councils of the party, I feel it my duty to warn the Fisheries Department that the carrying out of the present scheme to secure support for that party during the coming elections will compel all lovers of liberty, of whatever political persuasion, to unite in burling from power a Government that seems determined to eradicate from this country the last. vestige of British liberty and fair-play, and reduce an isportant class of our people to a position of political servitude unknown in any other portion of che British Empire.

Now, Mr. Editor, I will lay before your readers as briefly as possible an outline of the scheme referred to, and chalienge the Minister of Fisheries to deny its correctness. Should he deny it, my object wili be accomplished, as it will tend to show that the present programme will be abandoned. According to the present law, all holders of gili-net licenses are allowed to use for sailing boats 6,000 yards of net, and for tugs 12,000 yards. This amount is admitted by ail parties to be $a b-$ surdly smali and insufficient to pay running expenses, and yet the department has steadiiy refused to alter or amend the $12 \mathrm{w}$, though repeatedly urged to do so.

And for why ? Simply because they are determined to keep the fishermen at their mercy, subject to their dictation. Now, it is a fact that cannot be denied, that there is not a fisherman on Lake Huron, or Georgian Bay, but what is using mcre than four times the amount of net allowed by law. Wiil the Fisheries Department dare deny this ? I presume not, nor dare they deny that tishery overseers and Conservative politicians bave advised fishermen to isnore the law and use s.ll the nets they piease, urging them to show their gratitude in return in supporting the rule of the piesent Dominion Government.

And so on. But what I wanted to show is that it is a matter of notoriety that considerably more ne'ting is used than is allowed by the regulations of the department. I have talked with many practical fishermen and they tell me that it is simply impossible to carry on their business with the amount of netting now allowed by the department; they would simply have to quit the gill-net fishing business if they are to be compelled to fish in that way.

I have already referred to the injurious effects of the regulation respecting poundnets. light opposite the county of Essex, where our men are refused more than one net except in a few privileged cases, there are as many as 33 pound-nets in a string. This involves a great hardship. I brought one special case to the notice of the Minister mrself, the Black case. A poor fisherman had prepared for a second pound-net upon some promise of the fishery overseer, and had gone to ail expense, I think he said, of $\$ 300$ or $\$ 400$, which is a considerable amount for a fisherman-but afterwards was re- fused the additional license. I visited the department several times, und re. presented this matter to the hon. Minister, and it was a long time before he would grant the second pound-net even under these circumstances. It was only after affidavits had been produced to show that the promise had been made that the second pound-net was granted to this man Black, and that in the waters immediately opposite the county of Essex, there are as many as from 20 to 33 nets in a string, that the application was granted.

The lake opposite, I may say, is completely encompassed with nets. It is said there is as much as 700 miles of netting on the American side of Lake Erie, and this practically in the same waters as our own, because if a fish is not caught on one side it will be caught on the other. And yet even under these circumstances, we find the Minister hesitating and haggling with this poor fisherman and throwing him out of nearly a summer's work before granting hiln a second pound-net.

Another grievance, Mr. Speaker, is in reference to the licenses. A fee of $\$ 50$ is charged for a single pound-net. Thirtytwo men could fish 80 pound-nets, and on the present basis, thirty-two men would be paring more license fee than is paid by the 24,000 fishermen of. Nova Scotia. I would not go so far as to say that we should do away with all license fees. I would not go so far as to take the fisheries entirely out of Government contiol, yet the present system of patrolling the lakes, costing, as it does, over $\$ 20,000$ annually, is a very expensive system.

Another favourite theory of the hon. gentlemen and his professors is that fish remain in Canadian waters, and that this policy of restriction is in the interest of Canadian fisilermen and of the people of Canada. If that was so, if the fish was here for Canadians, there would be some justification for the policy. But I would ask the hon. gentleman, where this 800 million pounds of fish is to be found to equal the excess of the catch of American fishermen in the last 20 years. Why, Sir, if that theory was correct that Canadian ish remained in Canadian waters, ard that the 800 million pounds of fish renained here, the Canadian waters would teem with fisil, would be fairly alive with fish, there would be no depletion of our fisheries. That is a cumplete answer to the statement and argument of the hon. gentleman.

Now, another point is in reference to the whitefishery. The hon. gentleman said in his speech :

What was the staple fishery of Lake Erie only a few years ago ? It was the whitefish fishery. It was the whitetish that was turned over in the American market, it was the whitefish that brought gold to the fishermen on both sides of the lake. That is a superior fish, and a fish of great value. But there is no whitefish fishery on Lake Erle to-day. 
That statement is confirmed by the report of the Department of Marine and Fisheries for this year, containing a report by the captain of the "Petrel" that there is practically no whitefish in Lake Erie to-day. I would likc to ask the hon. gentleman where our whitefish have gone? It is said that they breed in our waters, that they are to be found in greater quantities on the Canadian side, and yet we are told there is no whitefish in Lake Erie to-day. The hon. gertleman was oblivious of the fact that this was an answer to his own contention that Canadian fish rernained in Canadian waters. I will tell him where the whitefish have gone. I will show by figures that. the American people have been catching an excess in whitefish quite as great as that in the other fish. As will be seen by the following table:-

Quantity of whitefish caught on both sides of Lake Erie in the following years :-

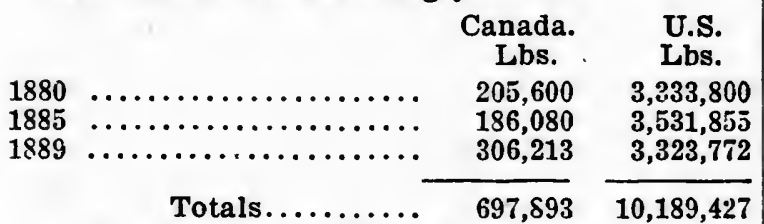

These figures show that the American catch on Lake Erie alone, in the single article of whitefish, is about 13 times greater than that taken by our own fisiermen. In 10 years, from 1880 to 1889 , taking the years mentioned as a basis of calculation. the figures would be: Canada, 2,326,310 pounds ; United States, 30,631,420 pounds. Vaiue: Canada, $\$ 189,104$; United States, $\$ 2,450,530$. If the Americans did not take another whitefish out of Lake Erie at the rate our fishermen have been permitted to operate, it would require 130 years' fishing on our part to catch up with the fishing on the other side of the Lake for the ten vears 1880 to 1890 . Now, I would like to ask where the whitefish are, if they do not cross the lake? It is quite evident from these figures that the whitefish in Lake Erie have been caught by the American fishermen, and that there has not been any overfishing on our side of the lake. The hon. gentleman, speaking of the fisheries oil the other side, says :

Ruin all round meets them and stares them in the face. I have the officlal evidence that their capital is moving west, tha' six or seven hundred thousand dollars in cold cash had been lost in the fishcry up to the last season, and that those remalning in the business were endeavouring to save themselves from absolute ruin by moving on to Lake Superior, and even further west, to the Lake of the Woods.

Wily, Sir, there is no doubt that American fishermen are moving on to Lake Superior and the Lake of the Woods; and if we go in to the figures relating to those lakes, we will find, relatively, perhaps, not as great a difference, yet a very great difference in erery one of those lakes as against the
Canadian catch. Now, Sir, as against this opinion of the depletion of the Lake Erie fisheries on the other side, I will just read a short extract from the New York "Sun" :

In none of the other great lakes do the conditicns for flsh seem to be so favourable as in Lake Erie. This is due in a great measure, ish culti:rists think, to the variations in the depth whlch are peculiar to that lake. The western end is shallow, and thus provides vast areas for spawning grounds. The deep water at the eastern end is an almost, boundless retreat for the half-grown young. The line between deep and skallow water seems to be drawn at Cleveland, for west of that city tho water is not more than 60 feet deep anywhere, and the average depth will, perhaps, fall balow 40.

Sir, we have only to turn up the reports bearing upon the fisheries of Lake Erie, to find that the fisheries, even on that side of the lake where this enormous fishing has been going on, are not in the frightful state depicted by the hon. gentlemen themseives. Ir 1893, an Amercian fisheries commission reported as follows on the condition of the Lake Erie fisheries :-

Although ranking fourth in area, this lake contains a fishing industry of vast extent and of much greater importance than that of all the other lakes ccmbined, omitting Lake Michigan, which it surpasses by 36 per cent in fishing population, 49 per cent in invested capital, 60 per cent in the quantity of fish taken, and 17 per cent In the value of the catch. The fisheries of Lake Erie are thought to be more important than those of any other body of fresh water in the world, and there are few, if any, lakes which have afforded such a history of prolificness of fish life in proporticn to their size. To lllustrate the relative productiveness of the American waters of this lake, it may be noticed that the average value of the catch per square mile of lake surface is only $\$ 200$, whlle in no other lake of this system is the average more than $\$ 50$, and in three of them is much less.

\section{The hon. gentleman says again :}

Our American neighbours, both official and unofficial, have met to deplore the rapid depletion of this great fishery and the decadence of this great industry. They have met in both on their own side of the liue and on this side to take counsel with thcir Canadian neighbours, having in view the great and to some extent the common interest. It is a notorious, and it is an exceedingly sad fact, that that is the condition of the Lake Erie fishery to-day. But there is more than this, Mr. Speaker, and it is to this point that I call the particular attention, and upon this I ask for the support of the House. The pollcy that, In spite of many difficulties, difficulties that it would be impossib:-j for me to exaggerate, I have endeavoured to uphold, is that of insisting on a rigid observince of the regulations-which I believe to be ne'cessary regulations-found in the Canadian Orders in Council governing Canadian waters of that lake and region. While there has been a diminution in the fishery, while the fish have fallen off on our side, we have not yet reached anything like the condition of our neighbours.

Let us now see how the American "people feel on this question, and whether they are alarmed to the extent stated by the Min- 
ister of Marine and Fisheries ? We find a report from Lansing in the Evening "News," of 1895, as follows :-

The hopes $c i$ the state fish commission, and many others, who believe that the great lakes are being depleted of whitefish, that the present legislature would enact some protective laws, have gone glimmering. A Bill to make November a closed season was discussed for an hour and a half in committee of the whole yesterday afternoon, and then killed. The chlef argument against it was, that no other state bordering on the lakes has a closed season, and until they do make one it is unfair to stop the business of Michigan fishermen at any season of the year.

That is the position they take in Michigan. They take a similar position in the state of Ohio. These are the states that are almost in proximity to our own border, and where there is not the slightest doubt that if fish are not caught on the one side they are caught on the other. I would ask the Minister, if he still holds the same view on this question, to send Professor Prince to the shore of the county of Essex, and he will find in large quantities, German carpe, a fish placed in American waters some years ago. 'I'his is a deep-water fish. They hare been coming on the shores of Essex for the purpose of spawning, and so thick are they that people hare come down to the lake at night, and the press of the county has called attention to the wholesale slaughter and destruction of these fish. This is positive proof that the fish go from one side to the other: Here is an additional proof, that our whitefish are caught by the Americans on the other side of the lake. The same re mark applies to the depletion of our fisteries if they are in the condition the Minister alleges, because, during the last thirty years, probably not less than $100,000,000$ pounds, approximately, of fish have been taken by the Americans out of Lake Erie more than have been caught by the Canadians.
Nova Scotia twelve years, that is, emplosing the whole 24,000 fishermen of that province, to make up a quantity equal to that to which I have alluded as having been taken by the Americans out of Lake Erie during the last 30 years in excess of the Canadian catrh.

The hon. Minister mentioned that we took narrow ground, that we confine our arguments and remarks to the shore of Lake Erie. The effects of this policy can be seen almost everywhere. The American fishermen are no doubt moving west to Lake Superior and the Lake of the Woods. I venture to say that from Lake Champlain to the Lake of the Woods, in all international waters, the Americans, through the stupid policy of our Government, are securing a great advantage over the Canadian fishermen. While our people are prevented from fishing, or only allowed to fish to a very limited extent, the Americans are reaping vast profits from an enormous trade. The figures relating to Lake Superior will bear out this statement. No doubt iis that great inland sea the regulations of the Fishery Department are less damaging, and probably far fewer fish cross the lake than in some of the other lakes to which I hare referred, but, nerertheless, we find that the American people on that lake are doing nearly all the business and are catching the greater part of the fish. Taking the years $1880,1885,1889$, as the basis of calculation of the catch and value of whitefish on both sides of Lake Superior for ten years, from 1880 to 1889 , inclusive, I find the yearly average to be : Canada, 618,720 lbs., value, $\$ 49,497$; United States, 3,575,8:5 ibs., value, $\$ 286,053$; and for the ten years named, in whitefish alone on Lake Superior there was nearly thirty million pounds excess, and in value, about $\$ 2,300,000$ excess in actual figures for the years named are as follows :-

YikLv and Value of Whitefish canght on both siles of Lake Superior-1880, 1885,

\begin{tabular}{|c|c|c|c|c|c|}
\hline- & \multirow{2}{*}{ Cauada. } & \multirow{2}{*}{ United States. } & \multirow{2}{*}{ Cents. } & \multicolumn{2}{|c|}{ 'Total Valee. } \\
\hline - & & & & Canada. & United States. \\
\hline $\begin{array}{l}1880 \ldots \ldots \\
1885 \ldots \ldots \ldots \ldots \\
1889 \ldots \ldots \ldots \ldots \ldots \ldots \ldots \ldots\end{array}$ & $\begin{array}{l}354,000 \\
606,160 \\
896,000\end{array}$ & $\begin{array}{l}2,257,000 \\
4,571,947 \\
3,898,558\end{array}$ & $\begin{array}{l}8 \\
8 \\
8\end{array}$ & $\begin{array}{r}828,32000 \\
48,49200 \\
71,68000\end{array}$ & $\begin{array}{r}\$ 180,56000 \\
365,75500 \\
311,81400\end{array}$ \\
\hline Total for three years...... & $1,8506,160$ & $3,578,835$ & & $\$ 49,49700$ & $\$ 286,053$ (k) \\
\hline
\end{tabular}

On that basis, for ten years at the same price per pound, as used by the Department of Marine anıl Fisheries, actual figures are :-Canada, 6,187,200 lbs.; United States, 35,758,350 lbs. Total value : Canada, \$494,970; United States, \$2,860,531). 
It would take fifty-seven sears fishing at the rate our men have been permitted to fish to equal the catch of whitefsh on
Lake Superior by the Americans in the ten years from 1880 to 1889 , including 1859 .

Trovt caught on both siles of Lake Superior in the Years 1880-1885-1887.

\begin{tabular}{|c|c|c|c|c|c|}
\hline & \multirow{2}{*}{ Canada. } & \multirow{2}{*}{\multicolumn{2}{|c|}{ Uniter! States. }} & \multicolumn{2}{|c|}{ 'Total Value. } \\
\hline & & & & Cauada. & $\begin{array}{l}\text { United } \\
\text { States. }\end{array}$ \\
\hline $\begin{array}{l}1880 \ldots \ldots \ldots \ldots \ldots \ldots \ldots \ldots \\
1885 \ldots \ldots \ldots \ldots \ldots \ldots \ldots \ldots \ldots \\
1889 \ldots \ldots \ldots \ldots \ldots\end{array}$ & $\begin{array}{l}\text { Lbs. } \\
312,800 \\
911,570 \\
1,020,500\end{array}$ & $\begin{array}{c}\text { Lbs. } \\
1,464,750 \\
3,488,177 \\
3,366,724\end{array}$ & $\begin{array}{l}\text { Rate. } \\
10 \text { cts. } \\
. ، \\
.6\end{array}$ & $\begin{array}{r}\$ \\
31,280 \\
91,157 \\
102,050\end{array}$ & $\begin{array}{l}8 \\
146,475 \\
348,817 \\
336,672\end{array}$ \\
\hline 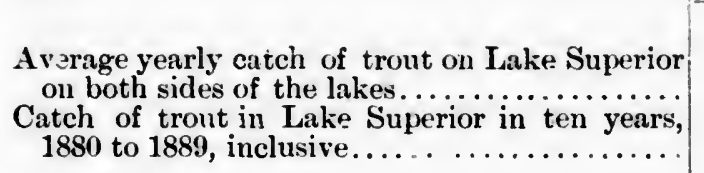 & $\begin{array}{r}2,244,8 \pi 0 \\
748,290 \\
7,482,900\end{array}$ & $\begin{array}{r}8,319,6511 \\
-2,773,217 \\
27,732,170\end{array}$ & ... & $\begin{array}{r}224,487 \\
i 4,829 \\
i+8,290\end{array}$ & $\begin{array}{r}831,994 \\
27 i, 321 \\
2,732,170\end{array}$ \\
\hline
\end{tabular}

Catcil of Whitefish and Trout on both sides of Lake Superior in ten Years, 1880 to 1889, inclusive, taking as a basis of calculation the average for Years 1880, 1885) and 1889.

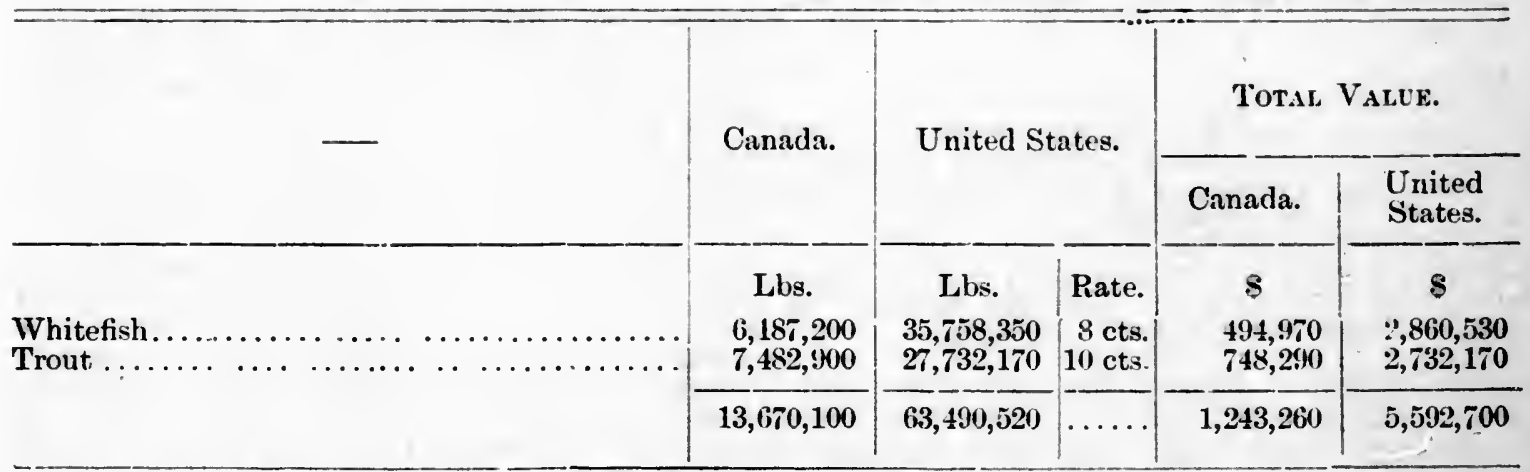

Loss to Canalians in ten years $50,000,000$ pounds whitefish and trout and over $\$ 1,000,000$.

Using the figures furnished by the Department of Marine and Fisheries, there was in this one lake alone, a loss of $\$ 4,000,000$ in ten years. According to that one-siciod fishery arrangement, it would take 48 years fishing on the Canadian side, to equal ten years fishing on the United States side of Lake Superior. Wherever you go, if you go further west to the Lake of the Woods, the American people are permitted to fish as the Minister says ad libitum. They are catching the fish while our Canadian people there and along the shores of the county of Essex, in the fishery districts. of Lake Erie, have been prevented from taking their fair share of fish.

The hon. gentleman has stated tuat there is no man from the Lake Erie district in this House who can rise in his place, and say that he really believes that the Lake Erie fisheries are now in as gocid condition as they were on account of the onslaught made on them from year to year by the fishermen on either side of the lake. I have given the figures which conclusiveiy prove there has been no extraordinary onslaught. I would like the hon. gentleman when he makes a statement of that kind to support it by statistics. Why, Sir, if the proper figures could be got at, they would show that we should have no less than $100,000,000$ pounds of fish on our side of the lake to equal the excess of American catch since 1870 , and it would take the entire catch of Nora Scotia ten or twelve years to make up the excess that the American fishermen have taken out of Lake Erie in the last thirty years.

\section{Sir CHARIES HIBBERT TUPPER. Hear, hear.}

Mr. ALLAN. The hon. gentleman says " hear, hear," but these are figures that he cau get from the Canadian blue-books, and from the census returns of the United States.

We have heard a good deal about some sort of reciprocal arrangement for a great many years. The hon. gentleman told us that it was the policy of the Government in $\mathbf{1 8 7 0}$, twenty-five years ago, and that it was also 
the policy of Mr. Mackenzie's Government. There might be some justifleation for a Government in power 20 or 25 years ago to try and preserve our fisheries by making certain regulations-aithough I belleve the regulations we have in force are entirely too severo-and to keep these rizulations in force expecting to make some arrangement with the American people. But every year this Government has utterly failed to do that, and the American people believe that the policy pursued by the Canadian Government is an erroncous and expensive policy. So long ago as 21st March, 1873, I find the following in the American Commissioner's Report :-

The Canadian laws are sweeping and stringent in character. By exacting license fees from the fishermen, they control the extent of fishing in all localities, and limit the number of nets to each mile of the shore in accordance with the judgmeut of the fishery officers. Their system of lawis and pollcing the whole extent of shores is an expensive and cumbersome method of protecting the fishes, and it is altogether probable tbat the large amount of money, $\$ 20,195$ in the year 1871, used for this purpose, would increase the products of their fisheries adapted to artificial culture.

\section{Again :}

Prohibiting fishing at certain seasons of the year has been an ordinary method of legislation in protecting the fish, and has proved to be of great advantage in streams and inland waters. The great lakes, in the particular of fishing, assume very much the character of the sea, and the same class of legislation, benefiting streams and inland waters, is not required for them.

The American people are pursuing their own policy from year to year and they refuse to enter into reciprocal regulation arrangements with Canada in reference to the lake fisheries. Every year they have been prosecting the fisheries without limit, and in Lake Erie catching eight fish to our one. Notwithstanding what the Minister says the catch is still maintained.

The hon. gentleman talks about failures, but I have never heard of them. I knew of the failure of a large fishing firm in the section of the country of which he spoke, but it was owing to their connection with the building of a large summer hotel at Put-In-Bay Island. The examination of the United States census returns relating to the profits of the American fishermen is a complete answer to the hon. gentleman's statement. It is shown there that the American fishermen are all making money, and that it has been a prosperous business. It is no argument to say that these fishermen are over crowded in Lake Frie. They have 700 miles of netting as the New York "Sun" recently stated, on the American side of Lake Erie, while on our side in the county of Essex, our fishermen there with equal advantages and equal facjlities could catch the same quantity of fish, have only about sixty pound-nets.
We catch in the neighbourhood of $\$ 100$,000 worth of fish annually, according to the values given by the Department of Marine and Fisheries, while on the American side the fishermen catch the enormous amount ci $\$ 2,000,000$ worth. Right opposite the county of Essex, the city of Sandusky, which is the largest fresh water fish market in the world, is carrying on an ellormous business. 'This luas been going on not merely for twenty or thirty years, but has been carried on since 1855 , which was about the time pound-nets were introduced. This trade was then commenced on a pretty extensive scale, and has been carried on by the Americans from year to year until they have so much fishing reparatis that it would probably be impossible for them to extend their business, while we on our side of the lake have been looking quietly ou.

Now, Sir, the hon. gentleman has been very much disturbed at times about the attacks that have been made by the fishermen and by the people of the country upon the policy of the department, and he has sent his professors to the Detroit River and to the western end of Lake Erie to make special reports upon this subject. A year ago, Professor Prince, who had arrived in this country, I believe, in April, visited the Detroit River, and when he returned to Ottawa lie wrote a special report justifying the position the department had taken. Speaking of close seasons, Professor Prince says :

That the enforcement of. close seasons and other protective regulations for whitefish on the Canadian side of the great lakes and border waters should have caused some discontent amongst Canaiian fishcrmen is not surprising. When the dividing waters are so narrow as in tile Detroit River, St. Clair Lake and river, such dissatisfaction is accentuated. The United States fishermen carry on their operations under no restrictions, anci at all available seasons. To our own fishermen, under whose eyes the American fishermen pursue the industry, the rigid enforcement of a close season and other regulations is peculiarly irritating. But any supposed advantages enjoyed by the United States fishermen are found, on strict inquiry, to be baseless, and on the other hand, the alleged grievances on the Canadian side in these waters have no better ground. As a matter of fact, the United States policy has proved most infurious to their own fishermen's interests and is wholly and emphatically disapproved by the leading men engaged in the fishiug industry in Detroit and other important centres.

Detroit, it may be mentioned, has one of the greatest fish-markets on the continent, and the view that prevails there is entirely in favour of the Canadian policy. It is not the case that the absence of restrictions on the American side has been detrimental to our fishermen, or that United States fishermen are reaping benefits, of which Canadian fishermen are deprived. Careful inquiries on the spot have abundantly shown that.

Any alteration in the existing close season would indeed be an injury to the Canadian fishermen and would bring serious results, leading rapidly to the total destruction of the whitefish fishery.

This is demonstrated by the following facts :- 
The Canadian side is, and always has been, the chief resort for the whitefish. The great fishmarkets of Detroit and elsewhere look to the Canadian side for their main supplies of whitefish, which breed and are hatched and reared in our waters.

And yet the hon. Minister, in the face of this important statement, and after llmiting the operations of Canadian fishermen in the way he has done, now telis this House and the country that the whitefisheries of Iake Irie are a thing of the past, This gentleman continues :

The November schools of whitefish, which pass up the Canadian side, are all spawners, just about to deposit theh' eggs. It is of the highest importance to protect them just at that time-a time which the present close season covers.

Parent fish in rivers and lacustrine waters, when ascending to the spawning grounds, always take the most direct course, and are not easily turned aside, as experienced fishermen are well aware. No more erroneous Idea could be entertalned than the supposition that whitefish wander aimlessly hither and thither from one side of a river or lake to the other. In these waters, as in other waters, it is certainly not the case that the schools of breeding fish deviate from their usual course, and cross from side to side so that fish caught by American fishermen during our close season would be caught by Canadians were they permitted to fish ai that time.

Not only has our side been the chief resort for the spawners, but the pollutions of Detroit city and numerous factories on the American side, as well as sewage and other deleterious matters, have tended to drive the whitefish to the purer waters on the Canadian side, and thus increased the school of spawners in our own waters.

The numberless nets, traps and pounds set in American waters and extending far from shore, intercept the migrating fish, break up the spawning schools, and drive them to our side. Our close season affords them freedom from these disturbances, and encourages them to come to our side.

Here we have the statement that Canadian fish will remain in Canadian waters, while American fish will cross over to Canadian waters. Prof. Prince goes on :

Perhaps the best testimony to the wisdom and utility of the department's regulations is furnished by the attempts to establish in the state of Michigan similar close seasons. Were the present policy on the opposite shores so highly satisfactory as many Canadian fishermen at times imagine, such attempts would never be made. So beneficial to all interested has the Canadian policy prover to be, in the opinion of many leading men in the state of Michigan, that, in order to save their fisheries from destruction in these waters, earnest efforts have been, and, no doubt, will be made again to imitate our restrictions and regulations and enforce them on the United States side. Were such uniform regulations enacted and enforced, the alleged grievances of Canadian fishermen would disappear, the planting and artificial propagation of whitefish on both sides would have fair-play, and the future welfare of these fisheries in these waters would be assured.

Here is Prof. Prince, a gentleman who had only recently arrived in this country, and who perhaps lrad never seen a whitefish before, alleging that the whitefish naturally resort to the Canadian side; but, in view of the confession of the hon. gentleman and the reports we have that our whitefish are absolutely gone, that Canadians have been prevented from taking their fair share, this is in $\mathrm{my}$ opinion a sweeping condemnation of the policy that has been pursued.

I would like to know on what ground sueh a policy can be justified unless for the good of Canada. If the hon. gentleman could show that his policy had developed the fisheries and that the fish were in Canadian waters for Canadiaus, although I believe his policy is serere in many respects, that would be almost a complete answer to the complaint that has been made against the Government polley. The hon. gentleman sent up another professor, or rather commander, who made a report in re. ference to the fish in the Detroit River. "Catch of whitefish and salmon-trout on the Detroit River by Prof. Wakeham," and the beauty of this thing is that not 50 trout have been caught in the Detroit River for the past 50 Jears. Yet one of these professors, a man with scientific knowiedge, a man who understands the movements of the fish and all about them, goes to the Detrolt River under the instructions of the hon. Minister and writes a report, no doubt, with the viow of supporting hls peculiar views and policy, giving an essay on trout in the Detroit River when no trout can be found there :

Whitefish and trout do not remaln long on the spawning grounds; they come in slowly, but directly they have spawned they return to deeper water. It is not the case that what are called Canadian fish are taken to any great extent in United States waters. A few may straggle from the schools, but the great mass of fish that spawn in our waters never get within reach of seines or pounds fished on the other side.

Here is another certificate from another professor who irofesses to understand the morements of the fish and to have great knowledge of the subject. He says that the Canadian fish do not cross from side. to side. Then I would like the hon. Minister to explain where the $800,000,000$ pounds' of fish, which is the excess caught by the Americans in the last 20 years or Lake Erie have gone. It seems to me they must have gone somewhere or other. If the fish do not cross from side to side, the Canadian fish must be on the Canadian side, and we should have an increase. In fact the fish should be so thick in Lake Erie that they would almost be in the way of the vessels. I believe, however, that the fish have gone into the Arrican nets and market. Take the statistic .... " b5 the Department of Marine and and you will find that the loss to Cany 2 in ten years is $\$ 20,000,000$ on Lake Erce alone. Yet the hon. gentleman will get up and say the statement that our fishermen are idle is an extravagant one. Why, the very fact that in the county of Essex, Including 
Pelee Island, there are only some 60 poundnets on one side and on the other side of the lake about 2,000 pound-nets, orer onehalf of which is almost immediately opposite, shows that our people are comparatively idie and have not been permitted to participate in the advantage of the rast and profitable trade which has been carried on many years by the American people.

Now, this is an important question. If hon. gentlemen would look into the figures in connection with our fisheries I am satisfied-although, of course, we cannot get back what we hare lost-that this stringent and ruinous policy would not be continued. The same thing will happen in Lake Superior which las happened in Lake Erie, if this policy prevails. The Americans will go and fish out Lake Superior. I ask what argument there can be for a policy of this kind, unless it can be shown that it develops the fisheries on the Canadian side. The very statements of the hon. gentleman, in the speech which $h \in$ distributed among the fishermen of the west, answer themselres The fish are not there. He admits that; but he talks of great onslaughts on the fisheries! There have been no such onslaughts. The fish have been taken by the American fishermen because the Department of Marine and Fisheries have prevented our fishermen from using the amount of netting and the amount of pound-nets which they could use to advantage. There is just one other matter to which I wish to refer before concluding. I allude to the state of disorganization that existed in the fishery district of Essex and Kent, comprising about half of Lake Erie. I read some papers in connection with this matter last session, in a hurried manner, because it was six $0^{\circ}$ clnck. 'The hon. Minister said he had not gone fully into the subject; he had not made an exkaustive review, but that my statements were meagre and all that sort of thing. 'There is nothing very profound about this subject, nothing that requires, as the hon. gentleman intimates, scientific knowledge. 'ithe fact simply is that the American people have been getting, through the connivance and sanction of the department, an immense advantage over our Canadian people. 'The statistics prove that; and when the hon. gentleman talks about people requiring scientific knowledge in order to discuss this policy, and the presumption of people who have not looked into the authorities and relying on a little horse sense doing so; it is enough to make the angels weep. Th hon. gentleman alluded to paper's that were brought down in relation to the dismissal of Mr. Prosser, and he said in reference to that matter :

I zreatly regret, owing to the importance of the subject, and notwithstanding the time at which it has beem brought to the attention of the House, that it will be necessary for me to ask the Indulgence of the House for some time while I refer to the points that have been raised hy the hon. member for South Essex (Mr. Allen), and particularly to the question upon which he only briefly touched. I know that it is contrary to the rules of the House, and very properiy so, to impute motives to hon. gentlemen who ask the attention of this body to any public question; but I was consicerably surprised, knowing, as I have reason to know, the very great importance of the preservation of the fisheries of the great lakes of this courtry, to observe this atternoon the extravagant language which that hon. gentleman indulged in, accompanied, as it was, by the most superficial statements that could possibiy be made on such a question. Time and again I heard the hon. gentleman, when speaking of the pclicy that I am carrying out, refer to it as, " a policy of oppression and tyranny" ; he spoke of "great ollirages" ; he stated that our Canadian fishermen on those lakes were practically idle today ; and deciared that there was no explanation cr defence in reply to an attack of great moment, which, apparently, had already been made this session, and which the hon. gentleman deemed it necessary on his part to follow up with his fusilade of this afternoon. These were extraordinary expressions, Mr. Speaker, and expressions which, if they had really a true support, would have excited a great deal more attention than the hon. gentleman was able to ccmmand on either side of the House, which would have attracted a great deal of attention this evening, and would have demanded the most serious consideration that we could give to them. But, instead of the hon. gentleman supporting those statements by arguments, or by an exhaustive review of what the policy of the department really was, I discovered a little later on in his remarks that his real object was to attack, not a policy, but a man ; not to criticise a minister of the department or the Government of the day, but to attack, in what I consider a most unfair manner, a Mr. Prosser, who, apparently, lives in the district from which the hon. member for South Essex cornes; and, although I have no knowledge of Mr. Prosser, apart from the fact that he was once an officer of my department and was dismissed, and that some years ago, yet, from what the hou. gentleman said, I have no doubt whatever that he is, whether rightly or wrongly, a strong man in that district, and a man who is politically opposed to the hon. gentleman. I can conceive of no other reason why the hon. gentleman should have spent the greater part of his time in driving home and repeating again and again the charges against this man, which were investigated as far back as 1891, and which brought about his ultiinate dismissal. What does the hon. gentleman want to do with Mr. Prosser ? Why does he drag him up before this House in this year of Our Lord 1894, and insist at a rather late period of the session in pounding him in the fashion he did?

It seems to me that I brought important papers before the House relating to the management of the Flsheries Department, It happened that Mr. Prosser was the fishery overseer in that district and was dismissed, and the hon. gentleman tried in this way to draw a line across the scent. He hoped by talking about Mr. Prosser to escape any other responsibility for this whole affair. Why, the return brought down was simply a disgraceful exhibition of the way the business of the Fisheries Department has been carried un 
in that section for years. You take these two districts flom Rondeau, westward. they comprise by far, the must important fisheries on the lake. And yet. for many years, a state of lawlessness and disorganization existed, which was simply a disgrace to the Fishery Department, and to the Government of Canada. The hon. gentleman may think that he can escape on the ground that he did not know that these things existed. It seems a queer idea of ministeriai responsibility to think that the hon. Minister can escape in that way. Why, Sir, although I have shown that the fisheries are practically in the hands of Americans from orer-fishing on their side of the lakes, yet, on our own sicle of the lake, comprising half of Lake Erie, the better half of it as regards the extent of the catch, the fishing was practically in the hands of one American firm, Post \& Co., of Sandusky, and our fishermen were for years mere serfs of these men, they dare not sell their fish except to Post \& Co., a license could not be giren except with the permission of Post \& Co., of Sanciusky. Though our fishermen were acting under the most rigid rules and re gulations, a state of disorganization existed, which the Minister of Marine is, to a very great extent responsible. I will just read part of the report of the special officer sent to investigate the state of affairs in this district. Mr. Kerr says :

I experienced a great many difficuities in fathoming the above irregularities

That is people fishing without a license, licenses being given to dead men, that kind of irregularities. -

-All sorts of obstacles were thrown in my way, especiaily from such of the fishermen as were under Post \& Co.'s control. This made it sometimes utterly impossible for me to get accurate, or even reliable, information in a great many cases, and I must come, therefore, to the conclusion, that either Post \& Co. own and control the whole fishery from Rondeau westward, or else that overseers McMichael and Prosser are in their favour, doing their bidding in every respect. instead of taking the interests of the department, whose paid servants they are. In addition to a most serious charge of mismanagement in recommending for licenses parties who do not exist, thereby helping to place the pound-net fisheries of Lake Erie in the hands of Yankee firms, I am also credibly informed that Mr. Prosser has been In the habit of granting permits for extra nets during the fall of the year, especialiy to such of the fishermen who dispose of their fish to Post \& Co.

\section{And again :}

I also found many fishermen afraid to give me the necessary information that I was seeking, on accounts of threats, \&c., made by Prosser and Post of taking away their licenses, \&c. One vid gentleman remarked, after I had taken his sworn statement, that, if Prosser knew it, it would settle his license for this year. There is no doubt this lawless sort of work has been carried on for years. If a fisherman makes a kick as to the price of his fish, \&c., the next year his outside pound is taken away from him. This particu- larly has caused much trouble, you can readily perceive-some enjoying the privilege of fishing iouble-headers, while other's applications are not entertained at all by overseer Prosser, who con. tended to some that the thing was not allowed.

Now, Sir, the hon. gentleman wanted to know why I brought up these papers which relate to 1891 . These papers were only brought down to the House in 1893. And the hon. gentleman was not present during that session, and I did not have the opportunity therefore of bringing the matter to his attention. I brought the subject up at the earliest possible moment, and I say it as a most singular thing that the Minlster of the Crown can escape all responsibility for the disorder that existed for years in relation to one of our most important lake fisheries. What sort of system can obtain in a Department of Marine and Fisheries, I should like to know, that it is possible for one American firm to control the fisheries of half Lake Erie for many years, as shown by the report of the hon. gentleman's own special officer. Prosser has been dismissed, the hon. gentleman says; and he thinks that that relieres him of responsibility. Why, Sir, here is a scandal which, while, of course, not in the line of the Curran bridge, yet involres a loss to this country quite as gleat as that involved in the Curran bridge-our fisheries practically handed over to one American firm for years; our fishermen not allowed to sell their fish to any one but Post \& Co., except in the case of one or two who positirely refused. It sinows that the Department of Marine and Fisheries under the hon. gentleman was not the model department that he would have the people of this country believe. It seems almost impossible that, under a well-regulated department such a state of affairs could exist, and be continued year after year.

We had hoped, Mr. Speaker, that some change for the better would take place in reference to the fisheries of the county of Issex. It was heralded by the local press, particularly by the Conservative press, of that county that there was to be an important change of policy, that our people were no longer to be deprived of the right to fish in the Detroit River, and these other narrow waters, they were not to be compelled to remain idle, while their American neighbours were gathering the fish, but that the same freedom in fishing would be allowed on our side as was allowed on the American side. Well, Sir, what change has taken place? In these narrow waters, the Detroit River and Lake St. Clair, Canadians are allowed to fish on paying $\$ 50$ license fee-on the other side it is entirely free-and, in November, the only month when it is possible to catch whitensh, they are prevented from fishing, while within a stone's throw, the Americans are gathering in the fish. I was in lopes tliat there would be a change in the policy of the department, but the hon. gentleman seeras to 
think that it is for the good of Canada that the old policy should remain in force. In order to show that, he must prove that the fish remain in Canadian waters, and remain there to be taken by Canadian and not American fishermen. If he cannot do that, it is quite evident that his policy has been a failure, and that there has been a very serious loss to the people of this country, a loss to Lake Erie alone, according to the figures of the hon. gentleman, in twenty years, of about \$40,000,000 , the excess of the American catch would be that much in value greater than the Canadian catch. That is the point, whether Canadian fish is here for tha Canadians, or whether they have been caught by the Americans. There is no profound knowledge required in this matter. If the fish are not here, it is quite evident that his policy is a failure.

I think it is due to this House and to this country that the hon. gentleman should give a little better explanation than he gave in his speech last year, and more reliable, leaving out such statements that these were really rery little; no difference in the catch in Lake Erie, that the figures were all talk, when the actual figures, as compiled from the blue-books of Canada, show that in the short period of twenty years, there is a difference of over 400 million pounds in that Lake alone. If we go ou and extend our inquiry, we shall find a very great difference also in Lake Superior. In the Lake of the Woods the same policy is being pursued, preventing Canadians from taking their share, and throwing the trade into the hands of the American people. Now, I think it is about time that hon. members should look into this matter, and that the people who are behind the Minister should compel a change of policy. It is about time that the leign of common sense should be ushered in. The idea of handing this enormous trade over to the American people, and year by year talling about some arrangement $b y$ which the fisheries can be preserved, while the American people continue catching as many fish as they possibly can, with all the appliances of nets and boats that they bring into service. This is an important matter, it is not a fish-hook and line buslness. Hon. nembers from the maritime provinces must understand that this is no ordinaly matter. If they compare the quan. tits of fish caught in Lake Erie alone, with the catch of New Brunswick, they will find that the catch of the Canadian and American side of Iake Erie is greater than that of New Brunswick. and it is not very much behind that of Nora Scotia. Yet the Minis. ter and the Govermment have thought that it is a wise policy to stand and look calmly on and prevent our people from fishing, and see the Americans enjoy this vast trade, a trade of $63,000,000$ pounds. Sandusky is the greatest fish market in the world, handling twenty million pounds of fish annually. I have not been guilty of using extravagant statements, as charged by the hon. gentleman; I have no desire to infringe upon his domain in that respect. I am sure that his statements, attributing to the McKinley Bill the results of the figures which have been presented, I have shown to be extravagant. As a matter of fact, the catch on the Canadian side is only seven or eight million pounds, and he can put that on, and it makes very little difference. Yet he will get up in this House and state that this difference is made up by the operation of the McKinley Bill, when I have shown that the figures were made up before the McKinley Bill came into operation. I think the hon. gentleman propounded a question in his speech that I. have forgotten to notice. He evidently thinks it is a clincher, and is an answer to the whole attack that has been made upon his department :

I would ask the hon. gentleman, how he will explain this to me, that, while the United States are spending mililions to our thousands in fish culture, yet it was my experlence to find a-request from the hatchery at Detroit, on the United States side of that narrow sheet of water, for permission to come into Canadian waters, in sight of the so-calied United States fishermen. io obtain the necessary quota of eggs for their hatchery, stating that they could not obtain thim on the United States side ? The reason is clear, and it is consistent with all the reports that I have been able to find-that our side of Lake Erie and our side of that river are peculiar.

Now, that is a great question. He wants to know why it was that Americans ask for permission to fish upon the Canadian side of the Detroit River, and if he establishes that there are a few more fish on the Canadian side of the river, he thinks his whole argument is established. Now, Professor Prince, in his report, saks of this very subject, and says that it is owing to the pollutions of the Detroit side, and I find that confirmed in the American report :

In earlier years there was a great abuudance of whitefish in this river, and the annual yield was very large. Mr. James Craig, of Detrolt, who has for many years engaged in the fish business of that city, informs us that near Fort Wayne, within the city limits of Detrolt, the average catch of whitefish in haul-seines was from 18,000 to $21,000 \mathrm{fish}$, weighing on an average from $2 \%$ to $27 \%$ pounds. On 12 th November, 1871 , at one haul of a seine, 3,100 whitefish were caught. With the growth of the city and the increase of the amount of sewage entering the river, the fisheries have deciined to their present condition. The number of whitefish taken in the vicinity of Fort Wayne in $18 \hat{\text { sิ }}$ was only 3,000 , and the output of the entire river was oniy 35,000 pounds.

That is the auswer to that statement. But hele the hon. gentleman makes another, whicli shows that after all he does not understand every thing in connection with his own department. The hon. gentleman says : "The great fish market for Detroit, especially in regard to whitefish, is in our waters." The hon. gentleman 
stated that requests were made by American hatcheries on Lake superior for eggs, and he wanted to know how it occurred that if their fisheries were not depleted they cane to the Canadian side for their fish eggs. In the waters of Lake Superior it is not possible to keep fish in Iens, which would necessarily be broken up, as can be done at Sandwich, and that is tho reason and the only reason why they cone and make requisition on our department for fish eggs. There is no scarcity of fish eggs in the United States. Here is a statement bearing on this subject :

Put-In-Bay, 15th May.-The haich at the fisl hatchery at this place beats the world's record in the number of eggs taken in one season at one station. During the year which will end with June, there have been taken at this station $11 \overline{5},-$ 000,000 whitefish eggs, $11,000,000$ ciscoes, or lake luerring ; 404,000,000 pike-perch, or wall-eyed pike, besides lake trout, grass pike, yellow perch and other varieties. Besides the eggs and fry shipped away, 3n,400,000 whitefish, $11,000,000$ ciscoes and $200,000,000$ bike-perch fry have been turned into the waters of Lake Erie.

There is no scarcity of fish eggs on the other side, as the hon. gentleman imagines. They have enormous quantities of them, and insteid of the fisheries being depleted, as tho hon. Minister endeavoured to show from extracts he read, I can read other extracts to show the reverse, and that in sume sections of the American waters there has been a great increase in the fisheries generally, and in the whitefish particularly. I read from the commissioners' l'eport of the United States Commission of Fish and Fisheries for 1892, as follows :-

Whitefish is the second important fish in Lake Huron. It is especially prominent in the poundnet fishery of that part of the lake north of Saginaw Bay and in the gill-net fishery from Alpena. The average weight of the whitefish is about 2 pounds.

Everywhere in this lake the effects of whitefish propagation are manifested and appreciated by the fishermen and fish-dealers. While the output in the year covered by this inquiry was somewhat less than in 1885 , the increase in the past few years has been marked. A prominent feature of the fishery for this fish was the unprecedentedly large run in many places of small fish of a size that had not been observed in abundance for many vears.

Again :

Along the shore, between St. Ignace and Detour, an increase in the abundance of whitefish, as compared with a number of precceding years, was reported, the increase being especially marked in Les Cheueaux and Pretence Bay. Trout and some other fish appear to be diminishing in number. One reason assigned by Mr. Isaac Go'1dreau, Mr. Charles Goudreau and other prominent fishermen for the increase of whitefish in the inshore waters and among the islands is, thist the fish have been driven from their regular resorts in the lake by the large accumulations on the favourite grounds of saw-dust and other refuse from a mill at St. Ignace.

The principal fishermen of this section think there will be no difficulty in keeping up the sup- ply of whitefish, if liberal consigciments of fry are planted annually, and the size of the mesh in the cribs of the pound-net is regulated so as to permit the escape of immature fish. In the vicinity of St. Ignace, the fishermen want also a law to prohibit the pollution of the lake, either by saw-dust or other refuse, and some favour a close season on all kinds of fishing after 1st Noyember for a period of years, in order to give trout and other fish whose abundance has decreased, a better opportunity to multiply.

In the fisheries of the southern slie of the Strait of Mackinac, and the adjacent western shore of Lake Huron, whitefish constitute fully nine-tenths of the catch, the remaining species consisting of trout, pike, perch, herring and sturgeon. During the last two years the number of whitefish in the fisheries could be carried to Mackinac city have been steadily increasing.

The only dealer at Mackinac city who has bought and handled fish caught in that vicinity during the past six years, says that it has been no uncommon thing in the last two years to take 2,500 pounds of whitefish from one small poundnet in one night's fishing, whlle in previous years, if half that quantity was taken under similar circumstances, it was considered a big catch : he is satisfied that the fish now being caught were planted in that vicinity by the Unlted States and Michigan Fish Commission.

In the vicinity of Cheboygan. while a great many trout are caught, whitefish is the principal specie. Every fisherman in this region has commented on the very large inerease in the number of whitefish caught during the past two years. Mr. Maynard Corbitt, of the fishing firm of Corbitt \& Duffy, stated that he had fished in that vicinity for twenty-five years, and up to two or three years ago the whitefish were becoming scarcer each season, hut during the past three years they have undergone a marked increase in abundance.

I could read many other extracts. It is very easy for the hon. Minister to read sta $^{4} \mathrm{e}-$ ments regarding the depletion of fishe les in certain sections; I could read about he depletion in other sections. That is not the question. 'The question is simply thls: has the policy of the department in preventing our people from taking a reasonable share of fish in Lake Erie, in preventing them prosecuting the fishery industry in that and other lakes, been a good policy ? I say the only answer that can be given to the question is to show that the Canadian fisheries have increased, and that we in Canada have a quantity equal to the great excess caught by the American fishermen. I regret that $I$ have been compelled to detain the House so long, but this is a question of very great importance, one involving a very large sum of money, one that gives employment to a rast number of American people, and if a proper policy had been pursued in Cauada our fisheries would have contributed very largely to increasing the wealth of the province of Ontario.

Mr. McGREGOR. I do not intend to take up the time of the House very long in speaking on this subject. The hon. member for South Essex (Mr. Allan) has gone over the points very clearly and has shown th? House the exact position we occupy as compared 
with our American neighbours. In the county of Essex we are very peculiarly situated. We have a shore line of about $\mathbf{1 5 0}$ miles. Along these shores we have our American neiglibours, in some places not more thau 2,700 feet distant from us. What we feel to be $n$ great grierance is that our Ameriean neighbours are allowed to fish from January to January, whereas our people are compelled to quit at the very time the fish are running. We have been fishing along these shores for 75 or 100 years. In a very large number of cases the fishermen have purchased the land along the shore for the purpose of getting the front from which to fish. The Government under its present policy, and under the policy that has been in vogue for many years, are depriving our fishermen of that privilege. While our shores are well adapted for the propagation of fish, we find that while the fish are small they remain there, but when they attain to that size to be of use to our people then the Americans are allowed to take them instead of our own people. The Minister stated that the fish do not go from one side of the lake to the other. But it will be found that according as the winds are the fish go for the deep and smooth water. So that if the Canadiaus are not allowed to fish, our American neighbours surely gct them. It. is stated also by the Minister that we are on the eve of having an arrangement made with our American neighbours, under which they will have a close season, the same as ours. For 20 or 2.5 years the same story has been going the rounds. Twenty years ago at a meeting in Detroit a proposition was made that the Americans should have a close season, but during the whole of those 20 years wo find no arrangements have yet been made. The Americans have taken our fish and our fishermen are becoming poor. We kuow that in the United States each state has a fishery law of its own, and Lake Erie, the Detroit River, the St. Clair Fiver, and sake St. Clair, are under the jurisdiction of four separate states, namely, Michigan, Ohio, Pennsylrania and New York. It would be almost impossible for Canada to make arrangements with the whole of these four states at one and the same time. We are asking only for fair play. We are asking that we be treated the same as our American neighbours who are on the shores of the same waters as we are. We ask that when they fish we can also fish. If they are determined to deplete the waters let us have our share. If our fishermen are allowed to fish all through the year, observing no close season, our neighbours may become alarmed and be led to proclaim a close season. But if they will not, and are determined to take the last fish, let us have our share of it. Why is it that the Amcricans can take fish by the thousands, and as my hon. friend (Mr. Allan) has said by the million, while we are die- prived of that privilege. We have petitioned the Government. We have shown the Goverument the necessity of a change in their policy. We have petitioned Parliament and the Government through the county councils of the counties in which we reside; we have petitioned through the town councils of the different towns along the horders ; and we have petitioned this House through the townships. Wé have also had individual petitions asking for a change of policy in reference to the fishing regulations, but, Sir, we have had no answer to any one of them. We feel that this is a great grierance. We feel that our people having invested a very large amount of money in the purchase of land for fishing purposes and then being deprived of the fish, are obliged to suffer a great loss. They have not only invested in the lands, but they have cleared the rivers for the purpose of fishing, and the fact that they have not been able to utilize their means of livelihood has left many of them in debt. They have lost their boats and their docks and many other investments they have made, all on account of the extraordinary and ruinous policy of this Government. Sir Charles Tupper said : Canada for the Canadians, but, Sir, the Minister of Marine and Fisheries has said : Canadian fish for the Americans. It is against the laws of Canada for a Canadian to have whitefish in his possession during the close season. The Government themselves come along and take large quantities of whitefish for the ova, and the fish being killed in the process, are sold to the Americans. The Canadians who have lived there so long, and who have enjoyed the fishing formerly, are not permitted to buy these fish even from our Cusiadian Government. The Americans have that privilege and honour. We feel that to be a great grierance. Talk about the Czar of Russia and his severity to Russian Jews. Sir, no Czar of Russia ever treated the Russian Jews as the people of Essex have been treated by these fishery laws. The Czar of Russia has been severe, but not so severe as the Minister of Marine and Fisheries. Not ouly does he keep the tish for the Americans, but when his officers find that a Canadian has made a mistake by fishing with a mesh a little small, or fishing outside of the close season, they seize his boat and break it up, they burn his nets, and the fisherman is taken prisoner. All this is done to him when he can stand at his own door and look across the river, which at many points is not broader than twice the distance from this House to Sparks street, and see his American neighbours take in fish by the thousands. We say that this is unfair and that it is ill treatment to Canadians. Now, Sir, we have no close season for herring in our fresh waters, and we find that ir. 1891, there were more herring in Lake Erie than there had been in any previous season. That shows that the policy of the Adminis- 
tration has not been in the best interests of Canadians. It is all the greater grievance, because it is we who grow the fish that the Americans catch. My friend from South Essex (Mr. Allan) has shown the rery large amount of fish taken by the American people and sold at Sandusky and other American towns. If this enormous quantity of tish is taken on the American side, it is largely because the people of Canada have been forced to protect the fish for the benefit of the American yeople. When we have the spawning grounds, and the feeding grounds and all the advantages, why should we not have our fair proportion of the fish. May I read, and that is all I will say on the subject, the following petition :-

To the Honourable the House of Commons of the

Dominion of Canada, in Parliament assembled :

The petition of the council of the township of Sandwich East, in the county of Essex, in the province of Ontario, humbly showeth : That the fishing interests of the province of Ontario are very valuable : that they belong to the people : that they shouid be administered in the best interests of the people; that in this province the most valuable fisheries are contained in the international waters which are common to the fishermen of Ontario and the United States; that in international waters the American fishermen have free fishing, are not restricted in the number or description of nets, and have practically no close season, while in Ontario our fislermen must obtain a license to fish, which places them under the control of the department, when applications may be discrininated against ; when granted, a high license is exacted; they are restricted in the number and description of nets, locations for fishing, a weekly close season impossible to observe by lake fishermen, various close seasons for different kinds of fish, and a general close season for the month of November ; to such an extent is over-protection carried that in Canada we have close seasons for mullets, suckers, sturgeon and herring,' which live largely upon the eggs of other kinus of fishes. Results-the American catch in the great lakes in three years, $1880-85$ and 1889the only years in which we have offlcial reportsthe American catch is : $1880,68,742,000$ pounds ; $1885,99,842,076$ pounds ; $1889,117,085,568$ pounds ; total in three years, $285,669,644$ pounds. Canadian catch in ail the great lakes and in lakes in Ontario, same years, was : 1850, $11,473,000$ pounds ; 1885, 27,378,180 pounds ; 1889, 32,169,032 pounds ; total in three years, $71,020,212$ pounds. T.he Americans employed in 1889 fishing in the great lakes 6,896 men, whose average catch was 16,977 pounds of fish. The Canadians employed in the great lakes in the same year were 3,529 men, whose average catch was 9,118 'pounds of fish. A comparison of the catch of fish in Lake Erie for the years $1880,1885,1889$.-The American catch was $144,217,149$ pounds, of which $10,189,427$ were whitefish. The Canadian catch in Lake Erie during the same years was $18,928,252$ pounds, of which 697,893 pounds were whitefish. The Americans employed 2,181 fishermen on Lake Erie in 1889 , whose average catch was 29,134 pounds. The Canadian employed 465 men in Lake Erie fisheries during the same year, whose average catch was 20,700 pounds. The value of the American catch in the great lakes in 1889 was $\$ 6,743$,359.19 ; the value of the Canadian catch in the great lakes in the same year was $\$ 1,963,122.80$; difference in favour of the Americans of $\$ 4,780$, 236.39. The value of the American catch in Lake Erie in 1889 was $\$ 3,248,361.66$; the value of the Canadian catch in Lake Erie in the same year was $\$ 487,604.47$; in favour of the Americans, \$2,$760,757.19$.

The prices of the various kinds of fish have been reckoned at the prices used by the Minister of Fisheries of Canada in valuing the fish caught in Ontario in 1889.

Under similar regulations there is no apparent reason why as many Canadians should not be engaged in the fishing industry as Americans, or that the catch on their side should not be as large as by American fishermen.

Your petitioners, therefore, pray that Canadian fiskermen be placed under the same system of free fishing as the American fishermen fishing in waters that are common to both, and that the fishermen of Lake St. Clair and Detroit River be granted permission to fish for whitefish in the month of November, the only month of the year that they are to be found in said waters.

And your petitioners will ever pray.

That is the case. so far as we can lay it before you in a condensed form. I thank the House for the hearing they liave given me. 